\title{
NUTRIENT MANAGEMENT IN SUGAR BEET: A REVIEW
}

\author{
Chandan Kumar Mahapatra, Tamalika Bhadra and Swapan Kumar Paul \\ Department of Agronomy, Bangladesh Agricultural University, Mymensingh 2202, Bangladesh \\ ${ }^{*}$ Corresponding authors E-mail: skpaul@bau.edu.bd
}

\begin{abstract}
Sugar is an important source of energy for the human body although it receives blame for many health problems, without it, the body would cease to function properly. Nearby thirty percent of the world sugar comes from sugar beet. Production of sugar beet globally spans diverse regions with a wide range of climatic and agro-ecological regions which shows exclusive management challenges. Fertilizer or nutrient management is one of the practices that associate with fertilizer use efficiency and production of the crops including sugar beet. As the nutrient management interacts with different agro-ecological areas and soils, the fertilizer recommendations and management have become regional and site-specific. Maximizing beet and sugar yields, the knowledge of the management of the fertilizers or nutrition is very essential. This article is to understand the impact of different fertilizers in different management practices including the major nutrients of the crop, fertilizer rate, timing, and method of application either solely or in a mixture or integrated manner with reviewing diverse research experiments. Moreover, it will help to approach future strategies and needs for making the production of sugar beet as a cost-effective crop with new improving management technologies for the farmers.
\end{abstract}

Key words: Sugar crop, fertilizer, nutrient, growth, yield, quality

\section{INTRODUCTION}

Sugar beet (Beta vulgaris L.) is an important sugar crop in the world due to relatively short duration, low fertilizer and water requirements compared to sugarcane. The taproot of sugar beet contains 13-22\% sugar (Heidari et al., 2008). Increasing sugar yield is a serious demand to meet sugar consumption or at least to decrease the gap between production and consumption of many countries in the world like Bangladesh. The sugar beet-producing dominating countries are Russian Federation, France, Turkey,
Ukraine, USA, Germany, UK, Iran, Belarus, Netherlands, China, Poland, Egypt, Italy, and Belgium (Kumar and Pathak, 2013). The yield ability of sugar beet depends on varietal potentiality along with agro-climatic and edaphic conditions, and also management practices. The importance of this crop comes from its ability to grow in the newly reclaimed soils and provides the growers under low soil fertility with profitable income (AbdelMotagally, 2015). Fertilizer or nutrient management is the science, practice, and art of understanding the source of fertilizer, placement, rate, and timing of application since they associate with fertilizer use efficiency and production economics. The nutrient management interacts with different agro-ecological areas and soils which brings about various recommendations for the different nutrients. The soil properties are the important dominating factors for the availability of plant nutrients. Sugar beet uptake of macronutrients (especially $\mathrm{N}$, $\mathrm{P}$, and $\mathrm{K}$ ) is considerable because it helps in following the natural cycle of the elements. Moreover, the plant 
$\mathrm{N}, \mathrm{P}$, and $\mathrm{K}$ balanced and harmonized requirements of a sugar beet crop could be estimated from the $N, P$, and $\mathrm{K}$ uptake, and hence maximum sugar beet yield could be approached (Wendenburg and Koch, 1996). Although easier to manage than $\mathrm{N}$, maintaining adequate amounts of phosphorus, potassium, sulfur, and micronutrients are also critical for maximizing sugar yields. Sugar beet plant is significantly responsive to micronutrient and its deficiency is one of the most important biotic stresses in plants grown especially on calcareous soils (AbdelMotagally, 2015). The micronutrient application specifically zinc and boron along with various mixtures of macronutrients may play an important role in the enhancement of yield and quality of tropical sugar beet was reported elsewhere (Bairagi et al., 2013; Kashem et al., 2015; Paul et al., 2018a and Paul et al., 2018b). When deficiencies of nutrients cannot be corrected by the direct applications of the nutrients to the soil, foliar nutrition is an option (Sarkar et al., 2007). Many investigators used the organic matter to fertilize sugar beet. Negm et al., (2003) found that the application of organic manure slightly increased cation exchange capacity, and reduced soil $\mathrm{pH}$. It was also observed that the available $\mathrm{N}, \mathrm{P}$ and $\mathrm{K}$ in the soil increased after the application of organic manure and reduced gradually by time to harvest. The objectives of this study is to review and reference those works and delineate the existing status of nutrient management for sugar beet, as well as to approach the future needs keeping sugar beet a cost-effective crop for the farmers.

\section{RESPONSE OF SUGAR BEET TO VARIOUS NUTRIENTS}

\section{Nitrogen}

Nitrogen as a major constituent of cell plays a vital role in cell division and elongation by virtue of being an crucial part of various type of metabolically active compound like amino acids, proteins, nucleic acids, prophyrins, flavins, purines and pyramidine nucleotides, enzymes, coenzymes and alkaloids (Murtaza et al., 2013). Nitrogen $(\mathrm{N})$ is a vital plant nutrient and a major yield and quality influential factor for sugar beet. Managing nitrogen has always been a balancing act for the efficient cultivation of sugar beet. Plants need nitrogen early in the season to put on weight, but too much late can cause sugar levels to fall (Snyder, 2017). Therefore, proper nitrogen management is critical for optimal sugar beet production. Compare to optimum dose the application of too little nitrogen will result in reduced root tonnage, however, the application of too much nitrogen will result in reduced sugar concentrations and increased impurities (Hergert, 2010).

Nitrogen

fertilization significantly increases soil fertility and crop productivity (Ahmad et al., 2017). In case of plant physiology such as leaf area, leaf area index, and photosynthetic rate can improve with the application of nitrogen which can eventually increase the yield (Cai and Ge, 2004). Nitrogen is probably the most studied nutrient for sugar beet because of its direct relationship to yield and it is the nutrient for most limiting plant productivity (Loomis and Conor, 1992). Nitrogen management is sharply linked to soil water relationships (Cariolle and Duval, 2006; Burkhart and Stoner, 2008; Coyne, 2008; Randall and Goss, 2008; Raun and Schepers, 2008). However, the challenging part of $\mathrm{N}$ management then arises determining the amount of $\mathrm{N}$ required producing the most profitable amount of sugar from the field. Proper $\mathrm{N}$ management, the $\mathrm{N}$ application, $\mathrm{N}$ uptake, and release must occur to allow good early canopy growth (Malnou et al., 2008). Nitrogen management must be maintained in 4-6 weeks before harvest without having excess N (Draycott and Christenson, 2003; Cariolle and Duval, 2006). As harvest approaches, $\mathrm{N}$ availability should truly decrease to promote boosted sucrose formation (Loomis and 
Nevins, 1963). Geypens et al. (1998) reported that due to increasing nitrogen rate more than the recommended dose $\left(80 \mathrm{~kg} \mathrm{~N} \mathrm{ha}^{-1}\right)$ increased root yield but decreased sugar content, while Paul et al. (2018a) noted that higher dose of nitrogen increased beet yield without significant hampering sucrose content in juice.

Managing $\mathrm{N}$ rate, placement and timing can be a challenge because of the uncertainty of precipitation in rainfed areas (de Koeijer et al., 2003). This can have $\mathrm{N}$ efficiency and significant effects on $\mathrm{N}$ use recovery because of $\mathrm{N}$ losses from denitrification or leaching (Coyne, 2008; Mulla and Strock, 2008; Francis et al., 2008). Most N recommendations in rainfed areas of Europe and North America are based on soil analyses.

Nitrogen application in rainfed areas has generally been reduced to spring time before planting through early in the growing season as a means of improving $\mathrm{N}$ use efficiency and reducing environmental effects, primarily leaching (Draycott and Christenson, 2003). In many irrigated areas, soils are developed under semiarid conditions and organic matter in soil levels are low resulting in low $\mathrm{N}$ mineralization (Carter and Traveller, 1981; Anderson and Peterson, 1988; Bilboa et al., 2004). Depth of root under irrigation often reaches at least $1.2 \mathrm{~m}$, but often extends below $1.8 \mathrm{~m}$
(Peterson et al., 1979). It was established in early research the importance of this means of improving $\mathrm{N}$ recommendations (Gilbert et al., 1981) and some other work established $\mathrm{N}$ uptake of sugar beet from deeper levels (Anderson et al., 1972). In Spain, pre plant measurement of soil nitrate in irrigated areas has also proven to be very effective in separating between responsive and nonresponsive sites (Bilboa et al., 2004). It was established that of $39 \mathrm{mg} \mathrm{kg}^{-1}$ was the critical level for maximizing root and sucrose yield. When a price correction was applied for sucrose content (a practice common in Spain and the US), the critical level was $33 \mathrm{mg} \mathrm{kg}^{-1}$. Above citation indicate that nitrogen is a vital nutrient for sugar beet and its management is very important for maximizing yield and quality.

\section{Phosphorus}

Phosphorus is a crucial element determining plants' growth and productivity by playing a vital role in cellular processes (Malhotra et al., 2018). Phosphorous is a component of nucleic acids and lipids and is important in the production and transport of sugars, fat and protein during sugar beet production (Ghaly et al., 2019). It is a critical macronutrient required for numerous functions in plant, including energy generation, nucleic acid synthesis, photosynthesis, glycolysis, respiration, carbohydrate metabolism and nitrogen fixation (Abel et al., 2002). Phosphorus is the second most limiting nutrient in comparison to nitrogen for sugar beet cultivation (Malhotra et al., 2018). It is especially important during early root development which ensures rapid root growth and good uptake of other nutrients. Phosphorus helps in the transfer of energy within the plant cells and moreover it regulates the structural integrity of cell membrane (Ahmad et al., 2017). Phosphorus deficient plants appear stunted, stiff appearance with darker green to dull blue-green leaves (Uchida, 2000). Phosphorus deficiency associated with soils in high $\mathrm{pH}$ and low in organic matter. Ismail et al. (2007) and Ouda (2007) reported that fresh and dry weights, leaf area index and root and sugar yields, as well as sucrose percent and sugar loss to molasses were increased as phosphorus rate increased up to $30 \mathrm{~kg} \mathrm{P}_{2} \mathrm{O}_{5}$ $\mathrm{fed}^{-1}$. Abdou et al. (2008) stated that increasing phosphorus fertilizer levels from 0.0 up to $30 \mathrm{~kg} \mathrm{P}_{2} \mathrm{O}_{5}$ fed $^{-}$ 1 , markedly increased root weight by 10.80 and $10.82 \%$, root yield by 17.56 and 17.72 $\%$ and sugar yield by 29.31 and $29.52 \%$ in the first and second seasons, respectively while Marinković et al. (2008) showed that increasing $\mathrm{P}_{2} \mathrm{O}_{5}$ from 50 to 100 and $150 \mathrm{~kg} \mathrm{ha}$ 1 resulted significantly increased root and sugar yields. Seadh (2012) reported that application of 30 
$\mathrm{kg} \mathrm{P}_{2} \mathrm{O}_{5}$ fed $^{-1}$, produced the highest values of growth characters and the highest values of the root, top, and sugar yields. Madani et al. (2014) explored that phosphorous fertilizer had a significant effect on sugar yield and the highest sugar yield $\left(0.98 \mathrm{~kg} / \mathrm{m}^{2}\right)$ was recorded when fertilized with $375 \mathrm{~kg} / \mathrm{ha}$ ammonium superphosphate as a source of phosphorous. Adding 31.0 $\mathrm{kg} \mathrm{P}_{2} \mathrm{O}_{5}$ fed $^{-1}$ maximize sugar beet root yield and quality (Abdou et al., 2014). Hussain et al. (2014) declared that the addition of phosphorus increased beet yield by 37 and $47 \%$ over control and Ghaly et al. (2019) noted that optimum phosphorus rate is $48 \mathrm{~kg} \mathrm{P}_{2} \mathrm{O}_{5}$ fed $^{-1}$ for efficient sugar beet cultivation. Results indicate phosphorus fertilization

increased beet yields and quality. Therefore, growers should be maintained optimum dose of phosphorus to maximize beet and sugar yields.

\section{Potassium}

Sugar beet is known as high potassium requiring crop (Johanson et al., 1971). According to assessments of Malakuoti (2000) potassium in plants has the role of catalyst and its shortage reduces resistance in plants against pests and plant diseases. Potassium has been shown to greatly improve early vigor and growth of sugar beets, particularly when producing optimum yield. Potassium plays an important role in the transport of metabolites in the phloem, particularly into storage tissues. Plants that accumulate large reserves of protein, carbohydrate, and sugar in their storage tissues have high $\mathrm{K}$ requirements. Potassium is the most abundant cation in plant tissues which has an essential role in metabolism (Mangel and Kirby, 2001). Potassium and its accompanying anions have a major contribution to the osmotic potential of cells and tissues of glycophytic plant species. It has a role in the nutritional balance that increases the organic compounds through the photosynthesis (El-Harriri and Gobarh, 2001, Gobarh and Thalooth, 2001). Dry weights and fresh weight of shoot and root were significantly affected by increasing the potassium level. The increase of fresh and dry weights of shoot and root caused by potassium fertilization could be attributed to the effect of $\mathrm{K}$ on the photosynthesis process in the plants and in turn, the translocation of sugar and carbohydrates of assimilates from tops to roots, which lead to increases in the root and sugar yield (El-Kholy et al., 2006). Potassium moves from older tissues to the growing points of the roots and tops since it is a mobile element in plant tissues. The beneficial effect of $\mathrm{K}$ fertilization on growth, yield, and quality of sugar beet was highlighted elsewhere (El-
Shafai, 2000; Zalat and Youssif, 2001; Attia, 2004; Abdel-Motagally and Attia, 2009 and Abdel-Motagally, 2009). The increase in recoverable sugar yields may be attributed to the role of $\mathrm{K}$ in nutrient uptake and nutritional balance which increases organic compounds through the photosynthesis process (Attia, 2004). Similar results were reported by AbdelMotagally (2009), AbdelMotagally and Attia (2009) and El-Sarag et al. (2013). Awad et al. (2013) stated that application of potassium @ $48 \mathrm{~kg} \mathrm{~K}_{2} \mathrm{O} / \mathrm{fed}$ resulted in a substantially increase in leaf area index and dry matter accumulation plant $^{-1}$, root length, root diameter, root weight, root yield, top yield, total soluble solids (TSS) and white sugar yield compared to other treatments. Potassium application @ 100 $\mathrm{kg} \mathrm{K}_{2} \mathrm{O}$ ha $^{-1}$ increased root yield, shoot yield, impure sugar percent, pure sugar percent and sugar yield under full and deficit irrigation over control (Mehrandish et al., 2012) while Kashem et al. (2015) noted that application of potassium significantly increased root and sugar yield and for appreciable yield tropical sugar beet requires more than $180 \mathrm{~kg} \quad \mathrm{~K} \quad \mathrm{ha}^{-1}$. Therefore, the highest potassium uptake by beet plants exerts the highest effect on yields of storage roots. Potassium uptake rate by beet plants might be is a prerequisite for an efficient 
uptake and function of $\mathrm{N}$. Excess of soil available $\mathrm{K}$ may lead to prolonged growth of tops. Above reviews indicate that potassium is a very important plant nutrient for sugar beet in terms of root yield and juice quality.

\section{Sulphur}

Sulphur is often referred to as the fourth major plant nutrient as it is an essential component of important metabolic and structural compounds (Thomas et al., 2003). Sulfur deficiencies in sugar beet are usually a yellowing of the leaf canopy. Sulfur deficiency in sugar beet results in a decrease of $\mathrm{CO}_{2}$ uptake and assimilation (Terry, 1976). As sulfur decreases below a critical level, chlorophyll content decreases which in turn decreases photosynthesis (Resurreccion et al., 2001). Compared to cereals and oil seed crops, sugar beet has a relatively low sulphur requirement (Syers et al., 1987) although it does have a requirement for a continual input of sulphur throughout the growing season to support the continued leaf growth and storage root development (Thomas et al., 2003). Response to sulfur fertilizers on sugar beets in irrigated areas is quite small because irrigation water often contains sufficient sulfate to meet $\mathrm{S}$ requirements. This problem was noted in California (Ulrich and Hills, 1969) but has not been reported as a concern in recent US research (Draycott and Christenson, 2003). If sugar beets are grown on soils with less than $1 \%$ organic matter and irrigation water levels of sulfate are less than $6 \mathrm{mg} / \mathrm{kg}, 10 \mathrm{~kg} / \mathrm{ha} \mathrm{S}$ may be applied. In higher rainfall areas of the USA, there have not been significant increases from sulphur application (Draycott and Christenson, 2003). Application of sulphur $(25 \mathrm{~kg}$ $\mathrm{ha}^{-1}$ ) resulted in a $25 \%$ increase in root yield together with significant increases in root and shoot dry matter accumulation (Thomas et al., 2003). El- Kammah and Ali (1996) and Hashem et al. (1997) indicated that yields of roots and sugar were significantly increased with increasing levels of applied sulphur. Application of $46 \mathrm{~kg}$ $\mathrm{S} \mathrm{ha}^{-1}$ along with other regular nutrients to sustain better root and sugar yields (Zengin et al., 2009). Sugar beets received $250 \mathrm{~kg} S$ fed $^{-1}$ produced the highest root and sugar yield was reported by Awad et al. (2013). Reviews have shown that sugar beet has a reasonably high demand of sulphur for enhancement its yield and quality. Therefore, proper management of sulphur is necessary for yield and quality improvement of sugar beet.

\section{Zinc}

Zinc is an essential micronutrient and it acts a stimulant in different types of enzyme systems which used for protein synthesis and carbohydrate metabolism (Madani et al., 2014). It is involved in different regulating key growth processes as it helps in the chloroplast development and in the metabolism of auxins (plant growth regulators). Enan (2004) stated that the role of $\mathrm{Zn}$ in assisting the utilization of phosphorus and nitrogen in plants might be responsible for the increase in top and root fresh weights gained by $\mathrm{Zn}$ application. Similarly the role of $\mathrm{Zn}$ in the metabolism of carbohydrates in plants may be influenced the increase in dry weight plant ${ }^{-1}$ by $\mathrm{Zn}$ application. According to Abdel-Motagally (2009) and Menisy (2009), top and root dry weights of sugar beet increase through the foliar spray with $\mathrm{Zn}, \mathrm{Mn}$ and $\mathrm{Fe}$ chelate. The beet yield increased by $14.5 \%$ and $21.8 \%$ over control with the application of 1.5 and $2.0 \mathrm{Zn}$ $\mathrm{kg} \mathrm{ha}{ }^{-1}$, respectively (Barłóg et al., 2016) and Zn @ 0.5 kg ha $^{-1}$ significantly increased sugar yield compared to the control. Beet yield, sucrose percentage increase by the foliar application of $\mathrm{Zn}$ up to $150 \mathrm{mg} / \mathrm{l}$ significantly whereas it decreases impurities in molasses (Attia and AbdelMotagally, 2015). Abd ElGawad et al. (2004) found that the $\mathrm{K}$ content of sugar beet root is increased significantly by the foliar application of $\mathrm{Zn}$. In addition, there is a significant effect of the foliar application of $\mathrm{Zn}$ on the sugar loss to molasses. Stevens and Mesbah (2004) applied Zinc fertilizer through 
broadcast, foliar, and seedrow application methods where seed-row-applied $\mathrm{ZnSO}_{4}\left(\mathrm{ZnSO}_{4}\right.$ at $6 \mathrm{lb}$ acre $^{-1}$, $\mathrm{Zn}$ at $2 \mathrm{lb}$ acre $^{-1}$ ) showed significant effect on root yield over the three year study and in comparison to control resulting in an 11\% (2.8 t acre $^{-1}$ ) root yield increase. Application $5 \mathrm{~kg} \mathrm{ha}^{-1}$ zinc on sugar beet significantly increased the yield and quality of sugar beet; the rate of increase was in the range of $4.62-6.97 \%$ in root yield, $2.09-5.75 \%$ in sugar percentage, $2.60-8.03 \%$ in white sugar percentage and 7.84-13.06\% in white sugar yield (Piskin, 2017). Many researchers reported the beneficial effect of $\mathrm{Zn}$ fertilizer application as a foliar application on the sugar beet yield (Nemeat- Alla and ElGeddawy, 2001; Enan, 2004; Menisy, 2009) who noticed that the highest applied level of $\mathrm{Zn}\left(150 \mathrm{mg} \mathrm{l}^{-1}\right)$ as a foliar spray results in an increase in yield or quality of sugar beet plants in calcareous sandy soils. Results indicate that sugar beet yield and quality are significantly influenced by soil or foliar application of zinc..

\section{Boron}

Boron plays an essential role in promoting cell wall formation, carbohydrate metabolism, and has been associated with sugar translocation (Ahmad et al., 2009). Boron deficiency has been understood as the second most vital micronutrients constraints in crop production after zinc. Sugar beet generally considered having relatively high requirements of boron as compared to other commodities (Tlili et al., 2018). It is primarily associated with production and transport of sugars to actively growing and developing roots of sugar beet (Barker and Pilbeama, 2007). Boron is by far the most important of the trace elements needed sugar beet because, without an adequate supply, the yield and quality of roots are very depressed. Soil application, as well as, a foliar spray of boron is equally effective, hence the fresh root weight, sucrose \%, root and top yields significantly increased by increasing boron levels. Armin and Asgharipour (2012) reported that the highest root yield and sucrose concentration was obtained by spraying with $12 \%$ boric acid. Soliman et al. (2014) showed that boron as foliar application significant responses in growth characters of sugar beet and exerted a significant increase in sugar, juice purity and crude protein percentage. Islam et al. (2015) reported that basal application of Boron @ 1.5 kg ha ${ }^{-1}$ increased beet yield, juice quality as well suppressed of crown rot incidence of tropical sugar beet. Abido (2012) stated that root yield and sugar content of sugar beet were increased with the application of boron @ 80 ppm. Applying boron@ @ 0.20 to $0.25 \mathrm{~g} \mathrm{~L}^{-1}$ twice at 80 and 110 days after planting the beet yield and quality were increased with foliar application of boron. Due to B application sugar yield recorded $7.52 \mathrm{t} \mathrm{fed}^{-1}$ and 9.42 $\mathrm{t}$ fed $^{-1}$ which were $65.17 \%$ and $\quad 46.14 \%$ higher respectively, compared to control treatment (Abbas et al., 2014). Application of boron solution @ 100 ppm at 70 days after planting (DAP) proved beneficial as it increased yield and quality of sugar beet (Abdel-Motagally, 2015). According to AlMohammad and Al-Gaddawi (2001), heart rot disease reduced significantly with the boron consumption of sugar beet when applied @1.2 kg B ha $^{-1}$. At the same time, due to increased glucose levels in roots and phloem sap, the sugar yield also increased. On the other hand AbdelMotagally (2015) carried out an experiment with boron concentrations $(0,50$ and 100 ppm) and various time of application (35, 70 and 105 days after planting, DAP), and the author found that boron, yield and quality traits of sugar beet were significantly increased by high concentration of boron. Narayan et al., (1989) stated that the highest yield of top $\left(18.6 \mathrm{t} \mathrm{ha}^{-1}\right)$ and beet $(49.58 \mathrm{t}$ ha $^{-1}$ ) were produced through the basal application of boron @ 20 kg borax ha-1 $(2.27$ kg B $\left.\mathrm{ha}^{-1}\right)$. Moreover, with the same treatment, it produced $14.92 \%$ sucrose in beet juice, total sugar content as well as at the same time improved 
the quality of sugar beet. Cooke and Scott (1993) reported that boron acts as the most important trace element demanded essentially by sugar beet. According to Gobarah and Mekki (2005) root length, diameter and root yield of sugar beet were increased with the application of boron @ $1.5 \mathrm{~kg}$ B acre $^{-1}$. Bithi (2019) found that $150 \mathrm{ppm}$ boron applied thrice at 40, 65 and 90 days after emergence is very effective for maximizing the beet yield, juice quality and suppression of crown rot incidence of sugar beet. Above results reveals that boron has tremendous influence on sugar beet yield and quality of juice. Both soil and foliar application of boron are effective in sugar beet. Therefore, an adequate supply of boron micronutrient is required to efficient cultivation of sugar beet.

\section{Manganese and other micro nutrients}

Manganese is an essential micronutrient with many functional roles in plant metabolism. It is a cofactor for enzymes involved in hydrolysis, phosphorylation, decarboxylation, and transamination (Schmidt and Husted, 2019). Manganese helps in the production of enzymes used for metabolism of proteins and fat. Application of manganese @ 25-30 kg ha-1 together with compound fertilizer increased the average root yield by $2.0 \mathrm{tha}^{-}$
${ }^{1}(+7 \%) \quad$ compared to manganese-free compound fertilizer (Erjala, 1986). Mekki (2014) reported that Manganese as sole treatment increased root length and diameter as well as fresh root weight of sugar beet. ElSherief et al. (2016) reported that the purity percentage significantly increased @ 2.0 $\mathrm{kg} \mathrm{fed}^{-1} \mathrm{Mn}$ application. Iron, $\mathrm{Mn}$ and $\mathrm{Zn}$ concentrations and uptakes by sugar beet roots significantly increase with increasing the foliar spray with Zn from 75 to150 $\mathrm{mg} \mathrm{l}^{-1}$ in comparison with the control treatment (Attia and Abdel-Motagally, 2015). Gobarb and Thalooth (2001) found that some micronutrients such as $\mathrm{Fe}$, $\mathrm{Mn}$ and $\mathrm{Zn}$ was important in meeting their deficiencies during the growth period as well as to increase yield components and yield quality of sugar beet. Gobarah et al. (2014) stated that the highest productivity and quality of sugar beet were produced by spraying micronutrients mixture $(\mathrm{Fe}+\mathrm{Zn}+\mathrm{Mn}+\mathrm{B})$ twice at 60 and 90 days after sowing @ 50ppm for each in the form of (Zinc sulphate, Manganese sulphate and Boric acid) and 100ppm in the form of Iron sulphate. Masri and Hamza (2015) stated that foliar application of the increasing levels of $\mathrm{Zn}+\mathrm{Mn}+\mathrm{Fe}+\mathrm{B}$ micronutrients increased yield attributes, beet yield, the total soluble solids (TSS), sucrose \%, purity $\%$ and extractable sucrose $\%$ of from sugar beet. In conclusion, $\mathrm{Mn}$ along with other micronutrients like $\mathrm{Zn}, \mathrm{Fe}, \mathrm{B}$ significantly influence beet yield and various quality parameters of sugar beet.

\section{RESPONSE OF SUGAR BEET TO MANURE AND INTEGRATED FERTILIZATION}

Organic manures are considered to produce higher crop productivity for sustainable agriculture. It provide nutrients to the soil and improve water holding capacity thus assist the soil to maintain better aeration for seed germination and plant root development (Zia et al., 1998). Hergert and Nielsen (2011) stated that of manure increased sugar yield significantly with no significant effect on sugar loss to molasses. Manure could be a valuable source of nutrients for sugar beet because it mineralizes slowly which can affect sugar content and impurities (Paul et al., 2018b). Topcuoğlu and Önal (2005) reported that poultry manure increased total yield and sugar content in sugar beet. The best application level of poultry manure was found at $10 \mathrm{t} \mathrm{ha}^{-1}$, but at the $40 \mathrm{t} \mathrm{ha}^{-1}$ poultry manure applications yield was declined. Gary at al. (2016) found that application of manure $20 \mathrm{tha}$ 1 increased sugar yield by $10 \%$ with no significant effect on sugar loss to molasses while Al-Labbody (1998) stated that increasing farmyard manure from 4.01 to $9.6 \mathrm{t} \quad \mathrm{fed}^{-1} \quad$ significantly 
increased sucrose \% and sugar yields. Although Kopczynski et al. (1999) found that application of vermicompost increased the yield of roots and sugar and enhanced the content of sugar in roots and, Zalat and Nemeat Alla (2001) confirmed that adding 6 tons farmyard manure/fed gave the highest values of sucrose\% (SC\%) and total soluble solids (TSS\%). ElAgrodi et al. (2011) noticed that that root quality parameters such as SC\%, TSS\%, purity and sugar yield significantly increased with chicken manure over the control and chicken manure along with gypsum significantly increased root yield. Marinhovic et al. (2004) found that the application of organic fertilizer increased the yield from 1.41 to $2.13 \mathrm{t} \mathrm{ha}^{-1}$. Similarly, Hassan (2005) indicated that the application of the organic fertilizers induced increases in the root yield, sugar yield, sucrose content, purity \% and the concentrations of NPK and micronutrients (Fe, $\mathrm{Mn}$ and $\mathrm{Zn}$ ) in roots. In addition, Paul et al. (2018b) reported that sugar beet fertilized with $75 \%$ recommended dose of NPK and other inorganic fertilizers + poultry manure @ 2.5 increased beet yield compared to sole application of inorganic fertilizers and poultry manure. Balakrishnan and Selvakumar (2008) stated that application of 100 per cent $\mathrm{N}$ through Urea along with FYM and biofertilizer provided the superior result in terms of tropical sugarbeet emergence, establishment, yield and quality although Hasanen et al. (2013) reported that supplying sugar beet with $350 \mathrm{~kg} \mathrm{~N}$ fed $^{-1}$ with FYM or PM resulted in the highest root and sugar yields fed $^{-1}$. Sohel (2016) noted that combined application of inorganic fertilizer Urea-TSPMoP@ @260, 100, 225 kg along with cowdung @ 10 t ha $^{-1}$ contributed the highest beet yield (90.49 $\left.\mathrm{t} \mathrm{ha}^{-1}\right)$. Above results indicated that sole application of manure or integration of manure with inorganic fertilizers increased yield and juice quality of sugar beet. Therefore, sugar beet growers can be used manures to curtail inorganic fertilizers as well as improvement of yield and juice quality of sugar beet.

\section{CONCLUSIONS}

Improving sugar beet productivity is a serious concern to the production of sugar for ever increasing population. The application of macro and micronutrients through fertilization is important for maximizing sugar beet productivity. The dose, timing, and method of application of those nutrients influence the yield performance of sugar beet. Above review of the literature mentioned that among the micronutrients $\mathrm{Zn}$ and $\mathrm{B}$ are highly responsive to sugar beet along with other macro nutrients like $\mathrm{N}, \mathrm{P}, \mathrm{K}$ and $\mathrm{S}$ and all of them have a tremendous influence on the growth, yield components, yield, and juice quality of sugar beet. Combined application of manure and inorganic fertilizer also influence root yield and quality of sugar beet. It seems that proper nutrient management is very essential to maximizing beet yield, sucrose yield, and also minimizes impurities in juice. Therefore, nutrient management is a critical factor in terms of yield and quality of sugar beet that should be considered to profitable sugar beet cultivation.

\section{ACKNOWLEDGEMENTS}

The financial assistance of Ministry of Education, Government of the People's Republic Bangladesh to conduct research on sugar beet is thankfully acknowledged.

\section{REFERENCES}

Abbas, M. S., M. D. H. Dewdar, E. I. Gaber and H. A. A. El-Aleem. 2014. Impact of boron foliar application on quantity and quality traits of sugar beet (Beta vulgaris L.) in Egypt. Res. J. Pharma. Bio. \& Chem. Sci., 5(5):143-151. 
Abd El-Gawad, A. M., S. A. H. Al-lam, L. M. A. Saif and A. M. H. Osman. 2004. Effect of some micronutrients on yield and quality of sugar beet (Beta vulgaris L.). II- Juice quality and chemical compositions. Egypt. J. Agric. Res., 82(4):1681-1701.

Abdel-Motagally, F. M. F. 2015. Effect of concentration and spraying time of boron on yield and quality traits of sugar beet grown in newly reclaimed soil conditions. Assiut J. Agric. Sci., 46(6): 1526.

Abdel-Motagally, F. M. F. 2009. Effect of potassium fertilizer and foliar spray of micronutrients on sugar beet grown in newly reclaimed soil. Minia J. Agric. Res. \& Develop., 29(2): 283-298.

Abdel-Motagally, F. M. F. and K. K. Attia. 2009. Response of sugar beet plants to nitrogen and potassium fertilization under sandy calcareous soil conditions. Inter. J. Agric. \& Bio., 11(6): 695700.

Abdou, M. A., N. M. M. Awad and M.E.M. Ibrahim. 2014. Influence of ploughing depth, phosphorus fertilizer level and thinning date on sugar beet productivity and quality. J. Plant Proc., Mansoura Univ., 5(12): 2037-2045.

Abdou, M.A., N. M. M. Awad and E. H. H. Selim. 2008. Effect of ploughing and phosphorus fertilizer levels on sugar beet productivity and quality. J. Agric. \& Env. Sci., Alex Univ., Egypt, 7(2): 1-11.

Abel, S., C. A. Ticconi and C. A. Delatorre. 2002. Phosphate sensing in higher plants. Physiologia Plantarum, 115:1-8.

Abido, W. A. E. 2012. Sugar beet productivity as affected by foliar spraying with methanol and Boron. Inter. J. Agric. Sci., 4(7): 287-292.

Ahmad, I., B. Ahmad, S. Ali, M. Kamran, H. Q. Fang and B. Bilegjargal. 2017. Nutrients management strategies to improve yield and quality of sugar beet in semi-arid regions. J. Plant Nutri., 40(15): 2109-2115.

Ahmad, W., A. Niaz, S. Kanwal and Rahmatullah. 2009. Role of boron in plant growth: a review. J. Agric. Res., 47(3): 329-338.

Al-Labbody, A. H. S. A. 1998. Effect of fertilization and harvesting date on yield and quality of sugar beet. M. Sc. Thesis, Fac. Agric., Al-Azhar Univ., Egypt.

Al-Mohmmad, H. and S. Al-Geddawi. 2001. Effect of Boron on Heart Rot and Yield of Sugar Beet. Arab J. Plant Protection, 19:45-48.

Anderson, F. N. and G. A. Peterson. 1988. Effect of increment-ing nitrogen application on sucrose yield of sugarbeet. Agron. J., 80: 709-712.

Anderson, F.N., G. A. Peterson, and R. A. Olson. 1972. Uptake patterns of $15 \mathrm{~N}$ tagged nitrate by sugarbeets as related to soil nitrate level and time. J. American Soc. Sugar Beet Tech., 17: 42-48.

Armin, M. and M. Asgharipour. 2012. .Effect of time and concentration of boron foliar application on yield and quality of sugar beet. American-Eurasian J. Agric. and Environ. Sci., 12(4): 444-448.

Attia, K. K. 2004. Effect of saline irrigation water and foliar application with K, Zn and B on yield and quality of some sugar beet cultivars grown on a sandy loam calcareous soil. Workshop on "Agricultural Development in the Arab Nation, Obstacles \& Solutions" Jan. 20-22, 2004, Assiut, Egypt.

Attia, K. K. and F. M. F. Abdel-Motagally. 2015.Influence of Potassium Fertilization and Foliar Application of Zinc on Sugar Beet Plants Grown on a Calcareous Sandy Assiut J. Agric. Sci., 46(6): 1-14.

Awad, N. M. M., H. S. Gharib and S. M. J. Moustafa. 2013. Response of sugar beet (Beta vulgaris L.) to potassium and sulphur supply in clayed soil at North Delta, Egypt. Egypt. J. Agron., 35(1): 77-91.

Bairagi, A., S. K. Paul, M. A. Kader and M. S. Hossain. 2013. Yield of tropical sugarbeet as influenced by variety and rate of fertilizer application. Pak. Sugar J., 28(4):13-20.

Balakrishnan, A. and T. Selvakumar. 2008. Integrated nutrient management for tropical sugarbeet hydrids. Sugar Tech., 10(2) 177-180. 
Barker, A. V. and D. T. Pilbeam. 2007. Handbook of Plant Nutrition (Books in Soils, Plants and the Environment). CRC Press, Boca Roton, Florida, United States. PP. 773.

Barłóg, P., A. Nowacka and R. Błaszyk. 2016. Effect of zinc band application on sugar beet yield, quality and nutrient uptake. Plant, Soil and Environ., 62(1): 30-35.

Bilboa, M., J. J. Martinez and A. Delgado. 2004. Evaluation of Soil Nitrate as a Predictor of Nitrogen Requirement for Sugar Beet Grown in a Mediterranean Climate. Agron. J., 96(1):18-25.

Bithi, S. 2019. Effect of foliar application of boron on the growth, yield and quality of tropical sugar beet. M.S. Thesis. Dept. of Agronomy, Bangladesh Agril. Uni., Mymensingh.

Burkhart, M. R. and J. D. Stoner. 2008. Nitrogen in groundwater associated with agricultural systems. In: Hatfield JL, Follet RF (ed) Nitrogen in the environment: Sources, problems, and management $\left(2^{\text {nd }}\right.$ ed $)$, Oxford, UK: Elsevier, PP. 177-202.

Cai, B. and J. Ge. 2004. The effect of nitrogen amount on photosynthetic rate of sugar beet. Nature Sci., 2(2): 60-63.

Cariolle, M. and R. Duval. 2006. Nutrition-nitrogen. In: Draycott AP (ed) Sugar beet, Oxford, UK: Blackwell Publishing Ltd, PP. 169-184.

Carter, J. N. and D. J. Traveller. 1981. Effect of time and amount of nitrogen uptake on sugar beet growth and yield. Agron. J., 73: 665-671.

Cooke, D. A. and R. K. Scott. 1993. The Sugar Beet Crop. Chapman and Hall London, PP. 262265.

Coyne, M. S. 2008. Biological denitrification. In: Schepers J. S. and W. R. Raun (ed) Nitrogen in agricultural systems, American Society of Agronomy monograph no. 49. Madison, WI, USA: American Society of Agronomy, PP. 201-254.

de Koeijer, T. J., A. J. de Buck, G. A. A. Wossink, J. Oenema, J. A. Renkema and P. C. Struik. 2003. Annual variation in weather: its implications for sustainability in the case of optimizing nitrogen input in sugar beet. European J. Agron., 19: 251-264.

Draycott, A. P. and D. R. Christenson. 2003. Nutrients for sugar beet production: Soil plant relationships, Wallingford, UK: CABI Publishing, PP. 7-32, 123-138, 180-181.

El- Kammah, M. A. and R. A. Ali. 1996. Responsiveness of sugar beet biomass to band applied sulphur and its effects on the profitability of potassium and zinc fertilizers under clay soils. J. Agric. Sci., Mansoura Univ., 21(1): 383-405.

El- Sherief, M. A. B., S. M. I. Moustafa and S. M. M. Neana. 2016. Response of sugar beet yield and quality to some micronutrients under sandy soil. Soil Sci. and Agric. Eng., 7(2):97106.

El-Agrodi, M. W. M., T. M. El-Zehery and H. L. Issa. 2011. Effect of chicken manure and gypsum on sugar beet (Beta vulgaris, var, Saccharifora, L.) under saline condition. J. Soil Sci. and Agric. Eng., Mansoura Univ., 2(6): 701-716.

El-Harriri, D. M. and M. E. Gobarh. 2001. Response of growth, yield and quality of sugar beet to nitrogen and potassium fertilizers under newly reclaimed sandy soil. The J. Agric. Sci., 26(10):5895-5907.

El-Kholy, M. H., M. T. Abdelhamid and E. H. H. Selim. 2006. Effect of soil salinity, nitrogen fertilization levels and potassium fertilization forms on growth, yield and quality of sugar beet crop in East northern Delta of Egypt. The J. Agric. Sci., 31 (6): 4049-4063.

El-Sarag, I. Eman and S. H. Moselhy. 2013. Response of sugar beet quantity and quality to nitrogen and potassium fertilization under sandy soils conditions. Asian J. Crop Sci., 5(3): 295-303. El-Shafai, A. M. A. 2000. Effect of nitrogen and potassium fertilization on yield and quality of sugar beet in Sohag. Egypt. J. Agric. Res., 78 (2): 759-767.

Enan, S. A. A. M. 2004. Effect of transplanting and soil applica- tion of boron and zinc on yield and quality of sugar beet. Ph.D., Al- Azhar University, Egypt.

Erjala, M. 1986. Control of manganese deficiency in sugar beet by placement of manganated compound fertilizer. J. Agric. Sci. Finland, PP. 58: 215-220. 
Francis, D. D., M. F. Vigil and A. R. Mosier. 2008. Gaseous losses of nitrogen other than through denitrification. In: Schepers JS,. Raun WR (ed) Nitrogen in agricultural systems, American Society of Agronomy monograph no. 49. Madison, WI, USA: American Society of Agronomy, PP. 255-280. Gary, W., G. W. Hergert and R. A. Nielsen. 2016. Effect of manure compost on sugar beet yield and quality. University of Nebraska Panhandle Research and Extension Center. 4502 Avenue I, Scottsbluff, NE 69361.

Ghaly, F. A., M. R. Abd-Hady, A. S. Abd-Elhamied and M. E. A. Mosallm. 2019. Effect of Varieties, Phosphorus and Boron Fertilization on Sugar Beet Yield and its Quality. J. Soil Sci. and Agric. Eng., Mansoura Univ., 10 (2): 115 -122.

Geypens, M., J. L. Vanongeva, P. Elst amd J. Bries. 1998: Evaluation of nitrogen fertilizer recommendations for sugarbeet on the nitrogen-index expert system. Commun. Soil Sci. and Plant Analysis, 29(11-14): 2217-2225.

Ghaly, F. A., M. R. Abd-Hady, A. S. Abd-Elhamied and M. E. A. Mosallm. 2019. Effect of Varieties, Phosphorus and Boron Fertilization on Sugar Beet Yield and its Quality. J. Soil Sci. and Agric. Eng., Mansoura Univ., 10(2): 115-122.

Gilbert, A. E., A. E. Ludwick and D. G. Westfall. 1981. Predicting in season requirements of sugarbeets based on soil and petiole nitrate. Agron. J., 73: 1018-1022.

Gobarah, M. E. and B. B. Mekki. 2005. Influence of boron application on yield and juice quality of some sugarbeet cultivars grown under saline soil conditions. J. Applied Sci. Res., 1: 373-79.

Gobarah, M. E., M. M. Tawfik, S. M. Zaghloul and G. A. Amin. 2014. Effect of Combined Application of Different Micronutrients on Productivity and Quality of Sugar Beet Plants (Beta vulgaris L.). Inter. J. Plant \& Soil Sci., 3(6): 589-598.

Gobarh, M. E. and A. T. Thalooth. 2001. Effect offoliar application with some micronutrients on sugar beet grown in newly reclaimed sandy soil. II-Effect on yield and yield quality. The J. Agric. Sci., 26(10): 5921- 5928.

Hasanen, G. H., I. H. Elsokkary, M. Z. Kamel and A. M. Abd Elsamea. 2013. Influence of nitrogen and organic fertilization on growth, yield and quality of sugar beet grown in calcareous soil. J. Plant Proc., Mansoura Univ., 4(5) $733-743$.

Hashem, F., S. El- Maghraby and M. Wassif. 1997. Efficiency of organic manure and residual sulphur under saline irrigation water and calcareous soil conditions. Egypt. J. Soil. Sci., 37(4): 451465.

Hassan, W. M. 2005. Effect of some organic fertilizers and sulphur application on yield quality and nutrient contents of sugar beet. J. Adv. Agric. Res., 10(4):965-977

Heidari, G., Y. Sohrabi and B. Esmailpoor. 2008. Influence of harvesting time on yield and yield components of sugar beet. J. Agric. For. and the Soc. Sci., 4(2): 69-73.

Hergert, G. W. 2010. Sugar Beet Fertilization. Panhandle Research and Extension Center.66. https://digitalcommons.unl.edu/panhandleresext/66.

Hergert, G.W. and R A. Nielsen. 2011. Effect of manure compost on sugar beet yield and quality. Conference Paper, March 2011. DOI: 10.5274/ASSBT.2011.88.

Hussain, Z., R. A. Khattak, M. Irshad and Q. Mahmood. 2014. Sugar beet (Beta vulgaris L.) response to diammonium phosphate and potassium sulphate under saline-sodic condition. British Soc. Soil Sci., 1-10.

Islam, M. S., G. M. A. Hossain, S. Islam, K. M. Alam, A. S. Mitu, M. S. Rahman, M. A. Haque. 2015. Influence of Boron on yield, juice quality and crown rot incidence of tropical sugarbeet cultivar 'Shubhra' grown at two AEZs of Bangladesh. Bangladesh J. Sugarcane, 36: 1-8.

Ismail, A. M. A., A. H. S. AL-Labbody and N. M. S. Shalaby. 2007. Evaluation of some sugar beet varieties under different combinations of NPK fertilizers. Egypt. J. Appl. Sci., 22(3): 77-90. Johanson, R. T., T. A. John, E. R. Geore and R. H. George. 1971. Advances in sugar beet production: principles and practices. The lowa State Univ. Press, Ames, lowa, USA.

Kashem, M. N., Q. A. Khaliq, M. A. Karim, A. J. M. S. Karim and M. R. Islam. 2015. Effect of 
nitrogen and potassium on drymatter production and yield in tropical sugar beet in Bangladesh. Pak. Sugar J., 30(2): 6-14.

Kopczynski, J., M. Bury and J. Denkiewicz. 1999. The influence of surface application of vermicompost and calcium on the yield and quality of sugar beet roots. Folia Universitatis Agriculturae stetinenis, Agricultura, 78, 94-54.(C.F. Field Crop Abst., 53(7): 4993-2000.

Kumar, R. and A. D. Pathak. 2013. Recent trend of sugarbeet in world. In: Souvenir- IISR-Industry Interface on Research and Development Initiatives for Sugarbeet in India, 28-29 May, Sugarbeet Breeding Outpost of IISR IVRI Campus, Mukteswar-263138, Nainital. Organised by Indian Institute of Sugarcane Research (ICAR) and Association of Sugarcane Technologists of India, PP. 46-47.

Loomis, R. S. and Conor D. J. 1992. Nitrogen processes. In: Loomis RS, Conor DJ (ed) Crop ecology: Productivity and management in agricultural systems, Cambridge, UK: Cambridge University Press, PP. 195-223.

Loomis, R. S. and D. J. Nevins. 1963. Interrupted nitrogen nutrition effects on growth, sucrose accumulation and foliar development of the sugar beet plant. J. American Soc. Sugar Beet Tech., 12: 309-322.

Madani, H., S. Borji and N. A. Sajedi. 2014. Effects of Zinc and Phosphoros fertilizers on Sugar Beet (Beta vulgaris cv. SBSI005 Crouse) yield in Iranian high Zinc alkaline soil condition. Scientific Papers. Series A. Agron., 57(2014): 240-245.

Malakuoti, M. J. 2000. General diagnosis method and essentiality of optimum fertilizers application. 5th ed. Tarbiat Modaress University Press, PP. 131.

Malhotra H., Vandana, S. Sharma and R. Pandey. 2018. Phosphorus nutrition: Plant growth in response to deficiency and excess In: plant nutrients and abiotic stress tolerance, Springer Nature Singapore Pte Ltd. PP.171-190.

Malnou, C. S., K. W. Jaggard and D. L. Sparkers. 2008. Nitrogen fertilizer and the efficiency of the sugar beet crop in late summer. European J. Agron., 28(1): 47-56.

Manngel, K. and E. A. Kirby, 2001. Principles of plant nutrition. Dordrecht: Springer.

Marinković, B., J. Crnobarac, G. Jaćimović, D. Marinković, D. V. Mircov and M. Rajici. 2008. Importance of increasing amounts of NPK nutrients on sugar beet yield. Res. J. Agric. Res., 40 (2): 99-104.

Marinkovic, B., L. Starev, J. Crnobarae, G. Jacimovic and M. Rajic. 2004. By products of sugar beet quality animal feed . Glasnik Zastite Bilja, 27(5): 114-118.

Masri, M. I. and M. Hamza. 2015. Influence of Foliar Application with Micronutrients on Productivity of three sugar beet cultivars under drip irrigation in sandy soils. World J. Agri. Sci., 11(2): 55-61.

Mehrandish, M., M. J. Moeini, and M. Armin. 2012. Sugar beet (Beta vulgaris L.) response to potassium application under full and deficit irrigation. European J. Exp. Bio., 2(6):2113-2119.

Mekki, B. B. 2014. Root Yield and quality of Sugar Beet (Beta vulgaris L.) in response to foliar application with Urea, Zinc and Manganese in newly reclaimed sandy soil. American-Eurasian $\mathrm{J}$. Agric. and Environ. Sci., 14(9): 800-806.

Menisy, M. G. A. 2009. Response of sugar beet to nitrogen fer- tilization rates and foliar application of zinc and boron under newly reclaimed soils at Fayoum. Ph.D. Fac. Agric. Fayoum, Fayoum University, Egypt.

Mulla, D. J. and J. S. Strock. 2008. Nitrogen transport processes in soil. In: Schepers JS, Raun WR (ed) Nitrogen in agricultural systems, American Society of Agronomy monograph no. 49. Madison, WI, USA: American Society of Agronomy, PP. 361-400.

Murtaza, G., M. M. Azooz, B. Murtaza, Y. Usman and M. Saqib. 2013. Nitrogen use efficiency in planmts under $\mathrm{NaCl}$ stress In Salt Stress in Plants: Signalling, Omics and Adaptations. Spinger Science, New York, PP. 415-433.

Narayan, D., A. S. Chandel and G. R. Singh. 1989. Effect of boron fertilization on yield and 
quality of sugarbeet (Beta vulgaris L.). Indian J. Plant Physiol., 32: 164-68.

Negm, M. A, M. M. Salib and H. EL-Zaher. 2003. A field trial on bio-composite sulphur application for improving the productivity for soil calcareous in natural Fayoum J.Agric . Res. and Dev. 17(1):77- 89.

Nemeat-Alla, E. A. E. and I. H. M. El-Geddawy. 2001. Response of sugar beet to foliar spraying time with micronutrients under different levels of nitrogen and phosphorus fertilization. J. Agric. Res., 27(4): 670-681.

Ouda, S. M. M. 2007. Effect of chemical and bio-fertilizer of nitrogen and boron on yield and quality of sugarbeet. Zagazig J. Agric. Res., 34: 1-11.

Paul, S. K., S. C. Paul, M. A. R. Sarkar and M. S. Hossain. 2018b: Influence of integrated nutrient Management on the growth, yield and sugar content of tropical sugarbeet (Beta vulgaris L.). Pak. Sugar J., 33 (2):11-22.

Paul, S. K., U. Paul, M. A. R. Sarkar and M. S. Hossain. 2018a. Yield and quality of tropical sugar beet as influenced by variety, spacing and fertilizer application. Sugar Tech, 20(2) 175-181.

Peterson, G. A., F. N. Anderson, G. E. Varvel and R. A. Olson. 1979. Uptake of 15N-labeled nitrate by sugar beets from depths greater than $180 \mathrm{~cm}$. Agron. J., 71: 371-372.

Piskin, A. 2017. Effect of Zinc applied together with compound fertilizer on yield and quality of sugar beet (Beta vulgaris L.). J. Plant Nutri., 40 (18): 2521-2531.

Randal, G. W. and M. J. Goss. 2008. Nitrate losses to surface water through subsurface, tile drainage. In: Hatfield J. L. and R. F. Follet (ed) Nitrogen in the environment: Sources, problems, and management, $2^{\text {nd }}$ ed, Oxford, UK: Elsevier, PP. 145-176.

Raun, W. R. and J. S. Schepers. 2008. Nitrogen management for improved use efficiency. In: Schepers J. S. and W. R. Raun (ed) Nitrogen in agricultural sys-tems, American Society of Agronomy monograph no. 49. Madison, WI, USA: American Society of Agronomy, PP. 675-695.

Resurreccion, A. P., A. Makino, J. Bennett and T. Mae. 2001. Effects of Sulfur Nutrition on the Growth and Photosynthesis of Rice. Soil Sci. Plant Nutri., 47(3), 611-620.

Sarkar, D., B. Mandal and M. C. Kundu. 2007. Increasing use efficiency of boron fertilizers by rescheduling the time and methods of application for crops in India. Plant Soil, 301: 77-85.

Schmidt, S. B. and S. Husted. 2019. The Biochemical Properties of Manganese in Plants. Plants, 8(381): 2-15. doi:10.3390/plants8100381

Seadh, S. E. 2012. Maximizing sugar beet yield with decreasing mineral fertilization pollution. Int. J. of Agric. Sci., 4 (7): 293-298.

Snyder, C. 2017. Nitrogen management in sugar beets important. article_44430bef-603b-551aa429-3ac1c710cbd8.

Sohel, M. A. T. 2016. Yield of tropical sugarbeet as influenced by variety, spacing, fertilization, date of sowing and intercropping with sugarcane. PhD Thesis, Dept. of Agronomy, Bangladesh Agril. Uni., Mymensingh.

Soliman, M. E., M. M. A. Hammada and A. E. Abd El-Nabi. 2014. Response of sugar beet plants to different compost types and boron spraying and their effect on growth characters and quality under ras sudr gonditions. J. Soil Sci. and Agric. Eng., Mansoura Univ. 5(10): 1363-1375.

Stevens, W. B. and A. O. Mesbah. 2004. Zinc enhances sugar beet emergence and yield on a calcareous soil with marginal Zinc availability. Crop Manage., 3(1): doi: 10.1094/CM-2004-080501-RS.

Syers, J.K., D. Curtin and R.J. Skinner. 1987. Soil and Fertiliser Sulphur in UK Agriculture. The Fertiliser Society, London.

Terry, N. 1976. Effects of sulfur on the photosynthesis of intact leaves and isolated chloroplasts of sugar beets. Plant Physiol., 57:477-479.

Thomas, S. G., T. J. Hocking, and P. E. Bilsborrow. 2003. Effect of sulfur fertilisation on the growth and metabolism of sugar beet grown on soils of differing sulfur status. Field Crops

Res., 83(3):223-235. 
Tlili, A., I. Dridi, S. Fatnassi, H. Hamrouni and M. Gueddari. 2018. Effect of Boron distribution in sugarbeet crop yield in two soils of Dour Ismail irrigated perimeter. Advances in Science, Technology and Innovation. PP. 417-423. doi. .org/10.1007/978-3-319-70548-4_131.

Topcuoğlu, B. and M. K. Önal. 2005. The effects of organic waste application on sugar beet: Part I- The effect of poultry manure on sugar beet. Akdeniz University Vocational High School of Technical Sciences. Environmental Pollution and Control Department, Antalya Turkey.

Uchida, R. 2000. Essential Nutrients for Plant Growth: Nutrient Functions and Deficiency Symptoms In Book: Plant Nutrient Management in Hawaii's Soils, Approaches for Tropical and Subtropical Agriculture J. A. Silva and R. Uchida, eds. College of Tropical Agriculture and Human Resources, University of Hawaii at Manoa, pp. 31-32.

Ulrich, A. and F. J. Hills. 1969. Sugarbeet nutrient deficiency symptoms a color atlas and chemical guide. Berkeley: University of California, Division of Agricultural Sciences.

Wendenburg, G. and H. J. Koch. 1996. Influence of variety characteristics on nitrogen uptake of sugar beet. Zuckerindustrie, 121(8): 623-630.

Zalat, S. S. and E. A. E. Nemeat Alla. 2001. Yield and quality of sugar beet as affected by inorganic and nitrogen fertilizer. Minoufiya J. Agric. Res., 26(5): 1187-1193.

Zalat, S. S. and O. A. N. Youssif. 2001. Effect of application time of potassium fertilizer and its ratio with nitrogen on the yield and quality of sugar beet crop (Beta vulgaris L.). Minufia J. Agric. Res., 26 (2): 401-408.

Zengin, M., F. Fatma Gökmen, M. A. Yazici, and S. Gezgin. 2009. Effects of potassium, magnesium, and sulphur containing fertilizers on yield and quality of sugar beets (Beta vulgaris L.). Turk J Agric For., 33: 495-502.

Zia, M. S., M. B, Baig, and M. B. Tahir. 1998. Soil environmental issues and their impact on agricultural productivity of high potential areas of Pakistan. Sci Vision, 4: 56-61. 